\title{
Renewable energy projects at municipal landfills
}

\author{
V. Pitruzzello \\ U.S. Environmental Protection Agency, Region II, New York City, USA
}

\begin{abstract}
This abstract describes how the New York City office of the United States Environmental Protection Agency (USEPA) is working with other U.S. government agencies as well as agencies from the Commonwealth of Puerto Rico to re-use municipal landfills for the generation of renewable energy.

Keywords: solar power, solar panel production, methane gas, incubator industries training, renewable energy, solid waste, power delivery system, alternative energy, carbon load reduction, photovoltaic cells.
\end{abstract}

\section{Introduction}

In September 2008, the U.S. Environmental Protection Agency (EPA) launched the RE-Powering America's Land: Siting Renewable Energy on Potentially Contaminated Land and Mine Sites initiative. EPA and the U.S. Department of Energy's National Renewable Energy Laboratory (NREL) are collaborating on a project to evaluate the feasibility of siting renewable energy production on potentially contaminated sites. EPA has provided more than $\$ 650,000$ through an interagency agreement that pairs EPA's expertise on contaminated sites with NREL's expertise in renewable energy. The project will analyze the feasibility of siting renewable energy on 12 sites across the country. The analysis will include, among other things, the best renewable energy technology for the site, the optimal area to locate the renewable energy technology on the site, potential renewable energy generating capacity, the return on investment, and the economic feasibility of the renewable energy projects. NREL will also pursue an analysis to explore the potential for siting alternative fuel stations (e.g., electric charging stations) at former gas station sites. 
RE-Powering America's lands includes assessments at five municipal landfills across the United States and also an effort in Puerto Rico to evaluate landfills for solar photovoltaic and landfill methane gas power generation. EPA obtained the technical services of NREL in a joint Federal agency initiative, to determine the viability of the landfills as potential sites as good candidates for solar power generation (use of photovoltaic cells) and for methane gas power use.

Once implemented, the strategy will allow communities with closed or decommissioning landfills to generate power for either on-site use (pump and treat systems, maintenance facilities etc.) and /or to sell power to the grid. Many of these communities are financially poor and power generation for on-site use or sale can help offset the funding needed by the communities for landfill closure operations and provide an opportunity to generate revenue beyond the closure of the landfill.

The focus of the remainder of this paper is on Puerto Rico's landfills being addressed through the efforts of RE-Powering America's Land project. A number of Puerto Rico landfills are under a closure order from the EPA. These large areas of land show much potential for the implementation of renewable energy generation. Specifically, the landfills could be utilized for solar power and landfill methane gas to energy technologies. The energy produced through these initiatives could be used for operation and maintenance (O\&M) of the landfills, and the surplus energy could be sold back to the utility grid in order to generate revenue. This revenue would help to significantly offset the overall cost of closing the landfill. With Puerto Rico's tropical setting and availability of many days of sunlight the use of solar power can be expanded island-wide. This will reduce the overall demand for imported energy and reduce the overall carbon load being generated on the island.

Based on the outcome of the feasibility studies being conducted by NREL, the Economic Development Administration (EDA), a division of the Department of Commerce, is in a position to provide funds to help attract industries for solar panel production through the creation of "incubator industries". Incubator industries could encourage the creation of jobs for the manufacture, installation and/or maintenance of solar panels or methane gas utilization systems to address Puerto Rico's high unemployment rate. The manufacturing jobs will be "green" in nature since the goal is to produce, install and maintain solar panels. Ultimately, Puerto Rico could be the hub of manufacturing and training for the southeastern mainland and other Caribbean islands purchasing such solar equipment.

The concept of placing large scale photovoltaic systems on a landfill site combines the capabilities of two types of renewable energy applications when accompanied by landfill methane gas. The sizes and technologies of the power plants allow for rapid scaling up and down of landfill methane gas facilities and predictable dispatching of power. Solar panel systems have dropped considerably in price and on a multi-megawatt basis, are cost competitive with new power plant construction, even when considering capacity factors. Solar 
panels can also be installed easily on the various topography of landfill sites and function properly.

\section{Participating organizations}

\subsection{Federal partners}

- U.S. Environmental Protection Agency. EPA's role is to oversee and ensure proper closure of a number of landfills regulated under the federal Resource Conservation and Recovery Act (RCRA) or listed on the Superfund National Priorities List (NPL). EPA will also act as a convener and facilitator to help move the renewable energy development process along to fruition. The EPA Brownfields program can also provide funds through competitive grants to establish job training centers and assist in creating "green jobs".

- U.S. Economic Development Administration. The EDA is part of the Department of Commerce. Its prime mandate is to generate jobs, help retention of existing jobs and stimulate industrial and commercial growth in economically distressed areas of the U.S. EDA has funds to provide the "bricks \& mortar" construction of incubator industries which create jobs. EDA can also partner with EPA job training facilities to help prepare students for "green jobs."

- U.S. Department of Energy. DOE's mandate is to advance the national, economic and energy security of the United States. DOE has funding resources to assist in evaluating the feasibility of solar energy and methane gas production projects, and it has extensive technical expertise, in part through the National Renewable Energy Lab (NREL), which other Federal and Commonwealth agencies can access. In addition, DOE provides block grant funding for states and municipalities which may be used to help municipalities evaluate the production of solar and methane energy.

\subsection{Commonwealth partners}

- Office of the Governor. The Governor's Office provides the political and logistical support needed to coordinate the efforts of the various other Commonwealth agencies and ensure that a cohesive, integrated program is developed and pursued.

- Puerto Rico Electric and Power Authority. PREPA's mission is to provide electric energy services to customers in an efficient, cost effective and reliable manner. Sale of energy produced at the landfills would need to be accepted into PREPA's grid.

- Puerto Rico Solid Waste Management Authority. The mission of SWMA is to assure, plan and implement strategies for the safe management of solid waste. SWMA's views and concerns must be incorporated into any plans for producing solar or methane gas as energy sources at landfills. SWMA 
may also be able to provide technical assistance to municipal landfill owners in pursuing these objectives.

- Puerto Rico Industrial Development Corporation. PRIDCO is a government-owned corporation dedicated to promoting Puerto Rico as an investment destination for companies and industries worldwide. PRIDCO can be viewed as the sister agency to EDA and is the Commonwealth agency involved in incubator industries and job creation.

- Puerto Rico Planning Board. The agency is responsible for preparing a Comprehensive Economic Development Strategy (CEDS). EDA requires a CEDS in order to apply for investment assistance under EDA's Public Works or Economic Adjustment Assistance Programs. The CEDS analyzes the regional economy and serves as a guide for establishing regional goals and objectives, developing and implementing a regional plan of action, and identifying investment priorities and funding sources. The Puerto Rico Planning Board appoints a CEDS Committee, comprised of public and private sector representatives, which is responsible for developing, revising, or replacing the CEDS.

- Puerto Rico Federal Affairs Administration. The PRFAA represents the Government of Puerto Rico before federal, state, and local governments, promotes the Governor's public policy initiatives to achieve a better quality of life for the four million U.S. citizens of Puerto Rico, and advises local government agencies and municipalities on issues of interest to Puerto Rico before the federal government.

- Puerto Rico Energy Affairs Administration. The Energy Affairs Administration serves a number of functions. This organization conducts studies and investigations to determine the needs of energy resources for Puerto Rico. They Recopilar información oportuna y confiable sobre la importación, manufactura, producción, distribución, elaboración, existencias, transportación, utilización y consumo en Puerto Rico de petróleo crudo $\mathrm{y} / \mathrm{o}$ sus derivados, así como de todo otro recurso energético.collect timely and reliable information on the importation, manufacture, production, distribution, processing, storage, transportation, use and consumption in Puerto Rico of crude oil and / or its derivatives, as well as any other energy resource. The Energy Affairs AdministrationIntegrar los asuntos energéticos directamente relacionados con los aspectos científico-técnicos y socioeconómicos, en especial, coordinar las políticas de aplicación general que pudieren ponerse en efecto como parte de la Política Pública Sobre la Energía de Puerto Rico y/o del Plan de Conservación de Energía. integrates energy issues directly related to scientific-technical and socio-economic factors, in particular, and to coordinate the policies of general application that could become part of public policy on the Puerto Rico Energy and / or the Energy Conservation Plan. The EAA Servir como agente de enlace y coordinación con el Departamento de Energía Federal y/o cualquier agencia federal que integre asuntos energéticos al nivel federal.serves as a liaison and coordination with 
the Federal Department of Energy and / or any federal agency to integrate energy issues at the federal level.

- Puerto Rico Department of Economic Development and Commerce. The Department of Economic Development and Commerce was created in 1994 as an "umbrella" under which several economic development agencies would operate in a more coordinated fashion. Among the agencies under its jurisdiction is the Puerto Rico Industrial Development Company (PRIDCO).

\section{Puerto Rico's current energy status}

Currently, the Puerto Rico Electric \& Power Authority (PREPA) has a capacity of approximately 4,200 MW of energy generation. Additional capacity is provided by private companies feeding into the overall grid, which is controlled by PREPA. The companies supply 400-900 MW of energy derived from oil, coal and natural gas. Consequently, the total capacity is approximately $5400 \mathrm{MW}$. In an effort to go greener, the Governor has announced that PREPA will convert in excess of $250 \mathrm{MW}$ from oil to gas. In addition, PREPA has signed three power purchase agreements each for $50 \mathrm{MW}$. Also, for facilities producing less than 1 MW, PREPA is required by law to buy any excess power. This is appealing if smaller solar plants go on-line, such as rooftops at parking garages, hotels etc.

It is important to note that virtually all of the energy generated in Puerto Rico is from oil and natural gas, which are imported. Consequently, renewable energy sources such as solar and landfill-gas-to-energy systems will serve a twofold purpose: (1) reduce dependence on foreign oil sources, and (2) mitigate greenhouse gas emission.

The Puerto Rico landfills are good candidates for solar power installation because most have adequate acreage for photovoltaic panel array installation. Each MW of power requires approximately 4-6 acres of land, so the generation from these landfills will fall in the acceptable range for solar projects of 2-5 MW of energy. Four keys things are necessary for this project to be a success: (1) land is made available to a developer (2) government support and involvement (3) PREPA power purchase price is economically advantageous, and (4) a willing developer. There are over 30 landfill sites in Puerto Rico in various stages of operation. Figure 1 shows many of the landfills in Puerto Rico.

\subsection{Landfill selection}

NREL will perform feasibility studies on the landfill sites slated for closure in Puerto Rico in order to determine which have the greatest potential for solar photovoltaic and landfill methane gas power generation systems. The NREL report will include the following information for each site:

$$
\begin{gathered}
\text { - Name and location, } \\
\text { - } \quad \text { Current load profile, } \\
\text { - Intention for power generation } \\
\quad \text { - Grid connected or }
\end{gathered}
$$


- Distributed generation to power remediation efforts or local needs

- Challenges to reuse,

- Description of specific solar technologies considered,

- Solar resource assessment,

- Incentives for renewable energy,

- Capital cost of optimal solar power generation system and

- Financing options.

Preliminary geographic information system (GIS) assessments of the landfills were conducted based on solar resource availability, topography and infrastructure. Several specific criteria can identify a landfill as having high potential for photovoltaic power generation as follows:

- Availability of adequate solar resource (all landfill sites in Puerto Rico have adequate solar resource),

- Acreage of site (greater than or equal to 14 acres),

- Slope of site (less than or equal to $20 \%$ ),

- Distance to transmission line (within in 1 mile), and

- Distance to graded roads (within 0.5 mile).

All landfill sites in Puerto Rico have sufficient solar resource to support photovoltaic power generation. Figure 2 demonstrates those landfills which meet the above stated criteria, resulting in 15 landfills which can be considered high potential sites for PV.

Even though all landfills in Puerto Rico have adequate solar resource to support solar photovoltaic power generation, the amount of sunlight and shading must be determined at each landfill site. NREL conducted sites visits to seven of the high potential landfill sites, and NREL staff employed a measuring device while on site at each landfill. Figure 3 shows a view of the sky throughout the year at one of the landfills visited, Toa Alta landfill.. As shown, there is minimal shading (the green regions indicate shading and the yellow regions indicate no shading) at the site with most of the shading occurring in the very early morning and the late afternoon hours during the winter and fall months. It should be noted that November is symmetric with January; October is symmetric with February, and so on.

\subsection{Landfill methane generation and use [4]}

Landfill gas is composed of a mixture of hundreds of different gases. By volume, landfill gas typically contains $45 \%$ to $60 \%$ methane and $40 \%$ to $60 \%$ carbon dioxide. Landfill gas also includes small amounts of nitrogen, oxygen, ammonia, sulfides, hydrogen, carbon monoxide, and nonmethane organic compounds (NMOCs) such as trichloroethylene, benzene, and vinyl chloride. 


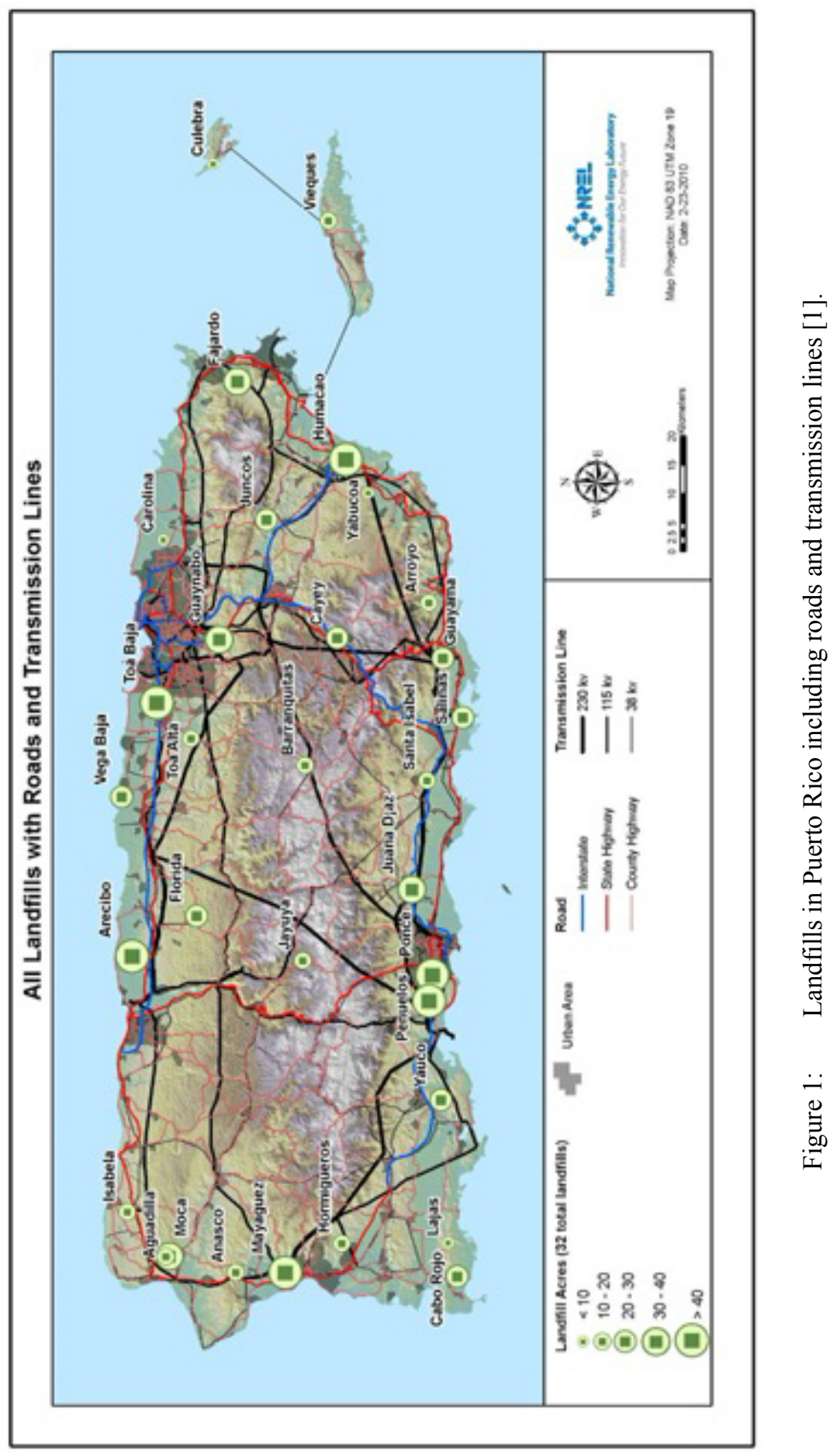


PII-68 Brownfields V

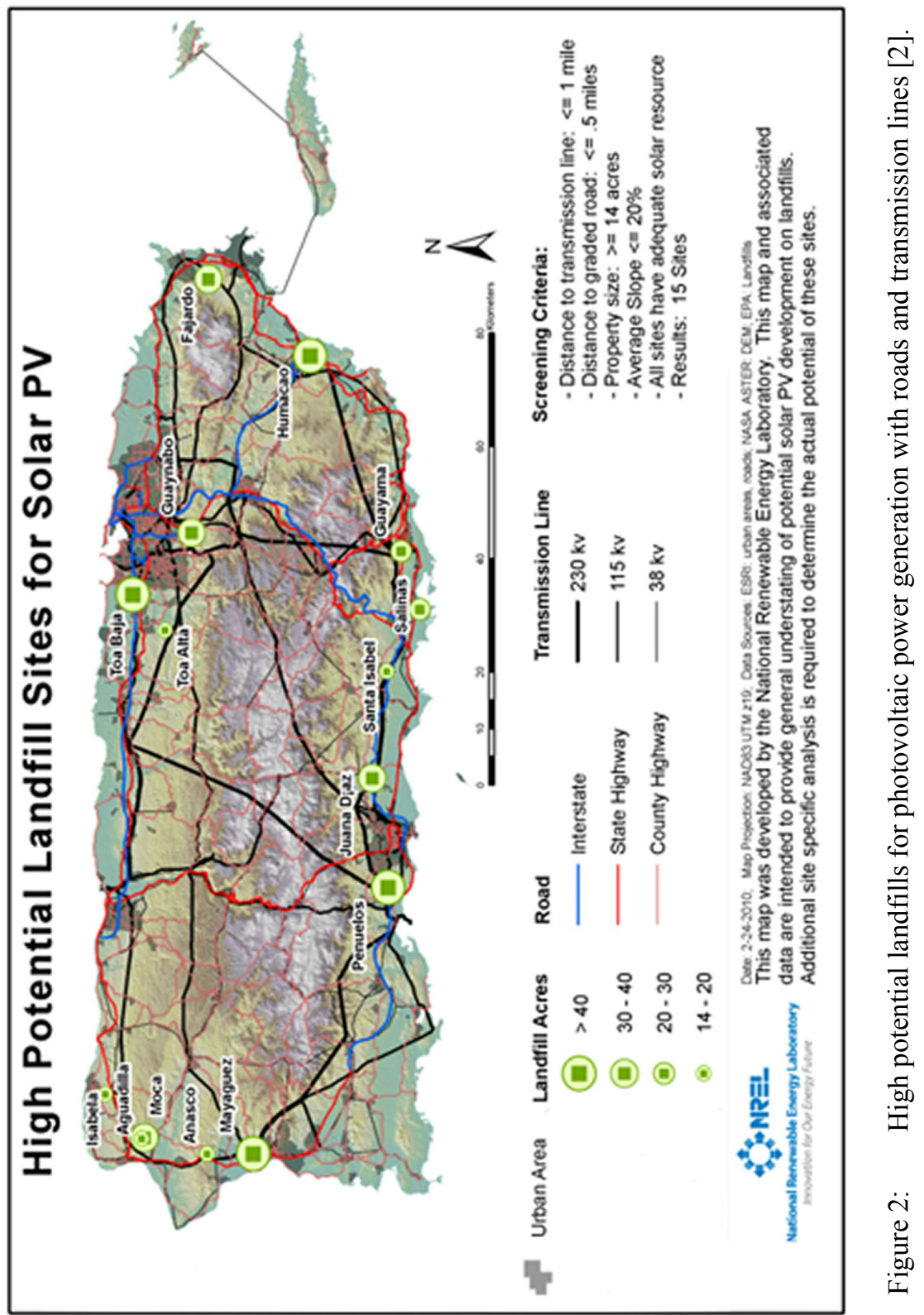




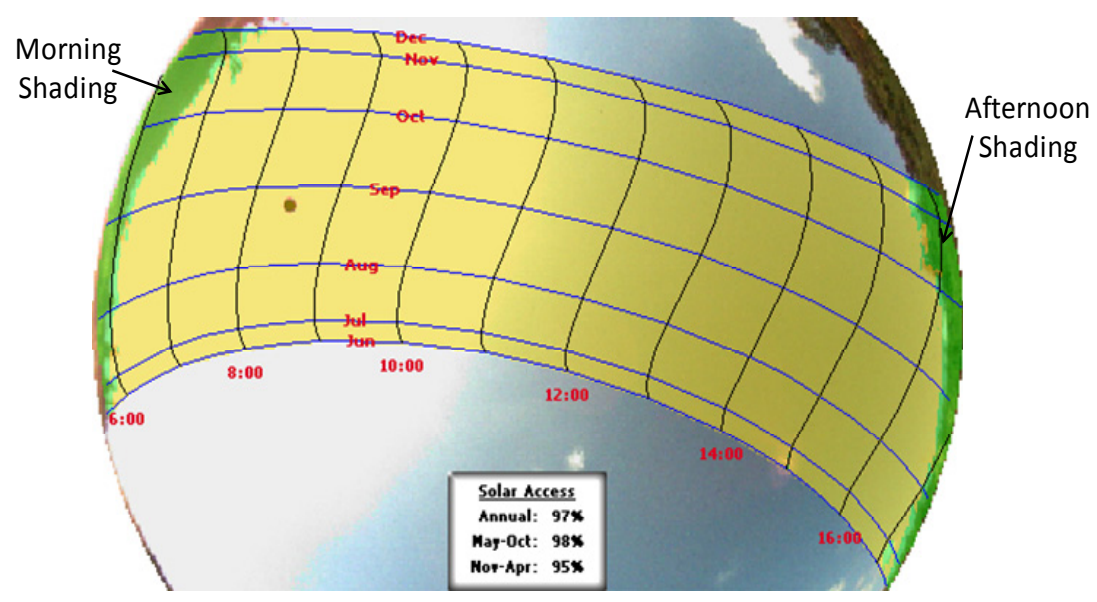

Figure 3: $\quad$ View of the sky - Toa Alta Landfill [3].

Landfill gas is produced via three processes:

- Bacterial decomposition. Most landfill gas is produced by bacterial decomposition, which occurs when organic waste is broken down by bacteria naturally present in the waste and in the soil used to cover the landfill. Organic wastes include food, garden waste, street sweepings, textiles, and wood and paper products. Bacteria decompose organic waste in four phases, and the composition of the gas changes during each phase.

- Volatilization. Landfill gases can be created when certain wastes, particularly organic compounds, change from a liquid or a solid into a vapor. This process is known as volatilization. NMOCs in landfill gas may be the result of volatilization of certain chemicals disposed of in the landfill.

- Chemical reactions. Landfill gas, including NMOCs, can be created by the reactions of certain chemicals present in waste. For example, if chlorine bleach and ammonia come in contact with each other within the landfill, a harmful gas is produced.

The rate and volume of landfill gas produced at a specific site depend on the characteristics of the waste (e.g., composition and age of the refuse) and a number of environmental factors (e.g., the presence of oxygen in the landfill, moisture content, and temperature).

- Waste composition. The more organic waste present in a landfill, the more landfill gas (e.g., carbon dioxide, methane, nitrogen, and hydrogen sulfide) is produced by the bacteria during decomposition. The more chemicals disposed of in the landfill, the more likely NMOCs and other gases will be produced either through volatilization or through chemical reactions.Age of refuse. Generally, more recently buried waste (i.e., waste buried less than 10 years) produces more landfill gas through bacterial decomposition, volatilization, and chemical reactions than does older waste (buried more than 10 years). Peak gas production usually occurs from 5 to 7 years after the waste is buried. 
- Presence of oxygen in the landfill. Methane will be produced only when oxygen is no longer present in the landfill.

- Moisture content. The presence of moisture (unsaturated conditions) in a landfill increases gas production because it encourages bacterial decomposition. Moisture may also promote chemical reactions that produce gases.

- Temperature. As the landfill's temperature rises, bacterial activity increases, resulting in increased gas production. Increased temperature may also increase rates of volatilization and chemical reactions. The box on the following page provides more detailed information about how these variables affect the rate and volume of landfill gas production.

\subsection{Economics- tax incentives [5]}

Puerto Rico enacted legislation in August 2008 in an effort to reduce its reliance on fossil fuels for electricity generation. Act 248 provides a corporate tax payer with a credit for acquiring and installing "solar electric equipment." The credit is allowed against the taxpayer's income tax. During fiscal years 2009-10 and 2010-11, the credit is 50\% of the cost equipment and installation. During fiscal year 2011-12 and beyond, the tax credit is limited to $25 \%$ of the cost of equipment and installation.

If approved, the credit shall be taken during the year of the installation. However, if the amount of credit exceeds the taxpayer's liability, the excess credit may be carried forward for up to ten years. In addition, full or partial credit may be transferred, sold or given to any other person.

The Executive Director of the Department of Revenue is authorized to issue up to $\$ 15,000,000$ of solar income tax credits to corporate tax payers per year, and has the authority to increase the total amount for any given year if it determines that increase to be in the best interest of Puerto Rico.

\subsection{Job creation}

The Economic Development Administration (EDA) will be a major partner in this undertaking. Their initial role will be to determine the feasibility of starting an "incubator industry" for the production of solar panels in Puerto Rico. This project provides potential for the creation of green jobs in production, installation, and maintenance of solar panels. Furthermore, Puerto Rico could become the central distribution center for solar panels in the Caribbean area, which has abundant solar resource.

If the feasibility study concludes that Puerto Rico is fit for such a project, the EDA can continue to play a significant role. They can provide technical assistance to develop a cluster analysis to identify supplier chain relationships, exporting capabilities and workforce development needs, as well as, assess the potential economic impact of achieving Puerto Rico's renewable energy targets in terms of a reduction in cost of energy and job creation. EDA can also attempt to renovate and fill empty PRIDCO facilities, and reinvigorate the 
competitiveness of communities and regions impacted by the downturn in manufacturing sectors. The EDA can also construct incubator facilities for supplier chain entrepreneurs engaged in the manufacturing of solar panels.

Collaboration with between the EPA, EDA, the Department of Labor (DOL), and academia can also provide green jobs training centers. EDA can supply "brick and mortar" funds, while the EPA and DOL can provide "soft costs," such as curricula development. Through the green jobs training centers, workers will be trained in all aspects of renewable energy technologies: manufacturing, installation, and operation and maintenance.

\section{Conclusion}

The EPA is still awaiting results from the feasibility study currently being conducted by NREL. These studies will provide a detailed analysis of each landfill that will be used to decide upon the final sites. If this project is successful, the generated electricity can be used for the operation and maintenance of the landfills, while the excess energy can be sold back to the grid, in order to help offset the costs of closure. The possibility of incubator industries in Puerto Rico also seems promising. Through the partnership between the EPA, EDA, and other key agencies, green jobs will be created in the areas of manufacturing, installation, and maintenance of renewable energy technologies.

\section{Acknowledgements}

I would like to acknowledge the following Agencies and their representatives for their generosity in providing the help and expertise in a joint effort towards moving these Brownfields projects forward. This kind of cooperation and sharing of knowledge, skills and ability is what makes projects not only successful, but also rewarding.

\section{U.S. Department of Energy}

Gail Mosey,

Senior Energy Analyst

Strategic Energy Analysis Center, NREL

James Salasovich,

Engineer II

Deployment \& Industry Partnerships, NREL

\section{U.S. Economic Development Administration}

Phillip Saputo,

Senior Program Analyst

Philadelphia Office (which covers the Carribean)

Department of Commerce - EDA/DOC 
PII-72 Brownfields V

\section{U.S. Environmental Protection Agency, Region 2}

Philip D. Flax, CHMM

Div. Enforcement \& Compliance Assistance

Elizabeth Smith,

Administrative Support - SEEP
Shannon O'Brien,

Environmental Engineer - Student Trainee

\section{References}

[1] Landfills with Roads and Transmission Lines -from NREL Map Projection NAD 83 UTM Zone 19 - Date 2/23/2010

[2] High Potential Landfill Sites - from NREL Map Projection NAD 83 UTM Zone 19 - Date 2/24/2010 Data Source ESR: Urban Areas Roads, NASA, DEM, EPA Landfills

[3] Toa Alta - View of the Sky from - NREL

[4] http://www.atsdr.cdc.gov/hac/landfill/html/ch2.html

[5] http://www.dsireusa.org/incentives/incentive.cfm?Incentive_Code=PR09F\& $\mathrm{re}=1 \& \mathrm{ee}=1$ 